\title{
Approaching the Language of the Second Language Learner: Interlanguage and the Models Before
}

\author{
Ayad Hameed Mahmood ${ }^{1} \&$ Ibrahim Mohammed Ali Murad ${ }^{2,3}$ \\ ${ }^{1}$ English Department, College of Educationt, University of Diyala, Diyala, Iraq \\ ${ }^{2}$ English Department, School of Basic Education, University of Sulaimani, Sulaimani, Iraq \\ ${ }^{3}$ English Department, College of Education \& Natural Sciences, University of Charmo, Sulaimani, Iraq \\ Correspondence: Ibrahim Mohammed Ali Murad, School of Basic Education, University of Sulaimani, \\ Sulaimani, Iraq. E-mail: ibrahim.murad@charmouniversity.org
}

Received: August 6, 2018 Accepted: September 13, 2018 Online Published: September 16, 2018

doi: 10.5539/elt.v11n10p95 URL: http://doi.org/10.5539/elt.v11n10p95

\begin{abstract}
The present paper attempts to provide a critical evaluation of the most prominent pedagogical models that have dealt with the language of the second language (L2) learner starting from the second half of the 20th century. The three most influential approaches in the domain are investigated in this study: contrastive analysis (CA), error analysis (EA), and interlanguage (IL). Each of these models is tackled in terms of its beginning, psychological background, essential tenets, mechanism, and its pedagogical value. Prominently, this work is aimed at teasing apart the confusion that surrounds the fields of acquiring second/foreign language. It also endeavors to clear out the overlapping of both terminology and concept that cloud these areas. Focus is placed on IL owing to the dominant share of attention it has received from researchers and applied linguists who have found many of their questions answered and many information-gaps filled in with this theory. This review paper is an extract of an in-progress $\mathrm{PhD}$ dissertation on interlanguage pragmatics of Kurdish university EFL learners, which is an applied study addressing both the pragmalinguistic and sociopragmatic knowledge of the students.
\end{abstract}

Keywords: interlanguage, contrastive analysis, error analysis, second language acquisition, learning strategies, language transfer

\section{Introduction}

Teachers and applied linguists have always been searching for the methods of teaching an L2 that may enable the learners to communicate with least amount of errors. Relying on trending schools of psychology that theorize the mechanism of second language acquisition (SLA), CA, EA, and IL have been proposed. Also, in the frame of these models, researchers (Lado 1957; Corder, 1967, 1981; Stern, 1983; Ellis, 1994, 1997) have attempted to account for L2 errors and explain their causes so as to suggest the appropriate solutions to be applied by teaching methodologists and L2 teachers.

CA, pedagogically associated with behaviourism and structuralism, flourished in Europe and North America during the 1950s and the 1960s. Scholars like Fries, Lado, Weinreich, and others were the distinctive researchers in the domain. Later in 1967 when the seminal paper of Corder, The Significance of Learner's Errors, EA appeared as a new and more welcome model to replace CA on one hand, and to signal the domination of cognitive psychology over behaviorism, on the other. With EA, according to this psychological framework shift, the orientation of pedagogists has switched from teaching to learning (Corder, 1967).

Shifting from the interest of accounting for the L2 learner to the brain-based system responsible for the errors has lead Selinker to hypothesize IL in a seminal article entitled Interlanguage in 1972. Psychologically, latent linguistic system of Lennberg (1967), who believed that language acquisition was an age-confined process, was the trigger of Selinker's IL theory besides his notice of the language of the L2 learner for being colored by forms which are neither of L1 nor of L2. Errors are attributed to different sources related to the basic processes of L2 learning. A detailed account of IL and the previous models are provided in the sections to follow. 


\section{Interlanguage Theory}

\subsection{What's Interlanguage?}

Technically, Interlanguage is a term with applied linguistic color. It is defined by its coiner, Larry Selinker (1972), who in his article Interlanguage, views this term as "a separate linguistic system based on the observable output which results from a learner's attempted production of a target language (TL) norm". His definition draws our attention to the oddness of the second language (L2) learner's language despite his/her attempt to follow the linguistic rules of L2. Additionally, labeling this linguistics system as a separate one implies that it is neither first language (L1)-like linguistic system nor an L2-like one.

Relying on Selinker's definition, Tarone (1994) swiftly paraphrases the technical term saying that "interlanguage is viewed as a separate linguistic system, clearly different from both the learner's native language (NL) and the TL being learned, but linked to both NL and TL by interlingual identifications in the perception of the learner". She adds that this linguistic system covers not only the phonology, morphology, and syntax, but also the lexical, pragmatic, and discourse levels of the interlanguage. Takač (2008), on the other hand, restricts this linguistic system to grammar, which sounds too limited.

Yule (1985) defines interlanguage as "An interim system of L2 learners, which has some features of the L1 and L2 plus some that are independent of the L1 and L2". This definition identifies the nature of such linguistic system as Yule refers to the L2 learner's language as a contemporary hybrid system deriving its norms from L1, conceptualizes interlanguage to be a matter of mental internalization of grammar by L2 learners, a natural language system that can be described in terms of linguistic rules and principles".

Considering the definitions of IL presented here, it will be quite logic to adopt Tarone's (1994) view and understanding of the term due to its clarity and comprehensiveness; the language an L2 learner cannot be confined to grammar as communication may never be possible by producing grammatical utterances only.

To label the language of L2 learners, other terms rather than IL have been used like, approximative systems, and idiosyncratic dialects (VanPatten \& Benati, 2000), but Selinker's term of IL has remained the most popular. Sridhar (1976) attributes this popularity to the appropriateness of the term to describe features of the L2 learner's language in terms of its instability (getting developed), its fluctuation (between L1 and L2 systems), and rule-governed tendency though inadequate in communication.

\subsection{Pre-Interlanguage Approaches}

Interlanguage (IL) is a theory that is located within the frame of second language acquisition (SLA) or foreign language acquisition (FLA) - of course without denying its contribution in learning an L2. It is an attempt to account for and probe into the errors committed by learners of second language (SL)/foreign language (FL) and their reasons.

Historically speaking, IL is not the sole approach to address the errors that are detected during the process of SLA/FLA. Two other prominent approaches were popular in the domain before IL appearance in the beginning of the 1970s: a. contrastive analysis (CA) and b. error analysis (EA). These two approaches are equally considered with IL in the domain of applied linguistics. It seems important to shed some light on these approaches before exploring IL theory.

\subsubsection{Contrastive Analysis Hypothesis (CA)}

This model has widely been associated with the school of structuralism, which was popular from the early decades of the 20th century till the appearance of Chomsky's transformational linguistics. The structural linguistics theorists have been inspired by the psychological school of behaviorists widely prevalent then; they were in the view that language learning is a matter of imitation and habit formation of the verbal patterns and that SL/FL learning gets more difficult when facing patterns that are different from the L1 or not found in it (Xia, 2014). In this strategy of structural linguistics, CA can be viewed as an application of structural linguistics.

CA is defined by Gass and Selinker (20012) as "a way of comparing languages in order to determine potential errors for the ultimate purpose of isolating what needs to be learned and what does not need to be learned in a second language learning situation". Importantly, besides the common tendency of CA to explain the errors of L2 learners relying on the differences between the linguistic systems of L1 and L2, this definition alludes that the comparison aims at expecting the errors which L2 learners may commit. The ability to predict errors of L2 learners is often referred to as the strong version of CA whereas the L1-based errors captured in their present performance are examples of the weak version (Wardhaugh, 1970).

Historically, this model was developed and practiced in 1950s and 1960s. Its emergence is specifically attributed 
to Charles Fries (1945). Later it was advocated by Robert Lado (1957), who in his Linguistics across Cultures, postulates:

We can predict and describe the patterns that will cause difficulty in learning, and those that will not cause difficulty, by comparing systematically the language and culture to be learned with the native language and culture of the student. In our view, the preparation of up-to-date pedagogical and experimental materials must be based on this kind of comparison.

CA theory lost its brightness for a couple of reasons: firstly because Chomskyism supplanted structuralism in the domain of linguistics, and secondly due to the emergence of more developed explanatory versions of analysis: Error Analysis (EA) and IL (see Richards, 1971; Schmidt, 2002).

To CA scholars, languages comparison benefit lies in its capacity to predict and to decide the areas of difficulty for their learners as SL. As Fries (1945) states, "The most efficient materials are those that are based upon a scientific description of the language to be learned, carefully compared with a parallel description of the native language of the learner". Thus, the focus of CA was comparing L1 and L2 to find out the similarities and the differences between the two at the communicative verbal and non-verbal aspects. The differences in linguistic patterns are thought to cause difficulties in L2 learning (Lado, 1957). Teachers were required to focus on such patterns and heavily expose the L2 learners to them in the classroom as a reinforcement technique to establish the targeted linguistic habits and avoid transferring linguistic or even cultural habits of L1 into L2 (ibid, p. 2). Transferring is assumed to occur when there is a difference between, for instance, a sentence structure of L1 and L2. This implies that it can be predicted how difficult learning a certain L2 can be. The more differences between $\mathrm{L} 1$ and $\mathrm{L} 2$, the more complicated the process of learning $\mathrm{L} 2$ will be and vise versa.

It is quite fair here to admit the merits of this hypothesis and its advantages in enriching the field of applied linguistics generally and SLA specifically. Saville-Troike (2006) amply expresses this notion stating:

CA stimulated the preparation of hundreds of comparative grammars (including many unpublished masters theses and doctoral dissertations at universities around the world), and its analytic procedures have been usefully applied to descriptive studies and to translation, including computer translation.

Additionally, in his acknowledgment of the practical aid that CA perceives in the errors of L2 learners, Alkhresheh (2016) explicitly confirms the value of the errors committed by L2 learners believing that they feedback both the teachers and the learners in terms the development of the task each is involved in the process of SLA. He sketches out three (ibid, p. 57) advantages of the L2 learner's errors stating:

First, they tell the teacher how far the learner has come and what he still must learn. Second, they give the researcher evidence of how language is learnt. Third, they are devices learners use to test out their hypothesis concerning the language they are learning.

With the conclusion of 1960, the hypothesis of CA has been severely attacked by applied linguistic scholars who were with the view of that it lacked consistency and objectivity in its procedures. Also, they believed that without describing L1 and L2 on the same standards, their CA results cannot be quite reliable (Brown, 1987; James, 1985; Wardhaugh, 1970; Whitman, 1970). Also, many predictions of CA have turned baseless according to Whitman and Jackson (1972) who proved that empirically. Lennon (2008) conspicuously sketches out the drawbacks of this hypothesis, which can be abstracted in the following issues:

a). CA perceives language learning difficulty spots as sources of errors. Surprisingly, such spots often receive special awareness by learners; thus, few NOT many errors get committed. CA scholars have misjudged the L2 learner's ability in building his/her own hypotheses.

b). CA attributes L2 learners' errors to the influence of L1 only.

c). Studies have proved the invalidity of what CA hypothesized concerning the dependence of the errors quantity on the distance between L1 and L2's linguistic systems and cultures - the further, the more. Thus, no reliability in errors prediction except the one of phonological nature.

To sum up, despite the CA's shortcomings in the facets previously touched upon, it can still be expedient for specific classes like translation as students of translation may easily learn about the dissimilarities found between the linguistic systems of the two languages under study. CA can be advantageous for researchers working on language families.

\subsubsection{Error Analysis (EA)}

EA has followed CA hypothesis in its emergence-probably, in reaction to the drawbacks of CA. However, it is seen as method that derived from the theoretical tenets of CA. Also, it is a model to assess and account for the 
errors of L2 learners in terms of causes and then evaluate and correct them, but without confining the causes of L2 learners' errors to the learner's L1. EA is also a behaviorism-based approach and linked to the school of structuralism.

According to Ellis and Barhkuizen (2005), error analysis is "de facto of the errors that learners make in their speech and writing". It could be quite plausible to state that EA is much wider in scope than CA as the former investigates both the linguistic and psychological aspects of SLA whereas the latter's focus is the linguistic only. To put it more precisely, CA's focus was the teaching materials, represented by L1 and L2 comparison, whereas in EA focus has shifted to the speech and writing - performance - of the learner of L2. Thus, it can be assumed that EA's research can validate what CA research predicts.

Crystal (1980) states that "In language teaching and learning, error analysis is a technique for identifying, classifying and systematically interpreting the unacceptable forms produced by someone learning a foreign language, using any of the principles and procedures provided by linguistics". It is via the errors, then, that an educator gets an idea of the strategies and hypotheses used by the L2 learner in the process of L2 learning; moreover, they enable teachers to monitor the level their students have reached in the class of L2 learning.

EA emerged in the 1960s on the hand of Steven Pit Corder and his colleagues (Corder, 1967). With EA analysis, the interest of applied linguists has shifted from prediction of SLA errors to assessment of SLA errors. EA deals with such errors that are frequent or systematic. Importantly, errors, in EA, are perceived as the key distinctness between the competence of a language learner and that of a native speaker.

CA and EA are opposite in their analytical directions. The steps followed in CA is to compare L1 and L2, and then spot the areas of difference- a step which may enables researchers to predict the difficulties or problems that will await L2 learners. In contrast, EA attempts to detect the errors actually made by L2, analyze them and find out their areas, and by then contrast only those located areas. In EA, "the assumption is that the learners' grammatical and appropriate utterances are evidence that he is at least in part using the categories and systems of the target language correctly and appropriately" (Corder, 1981). Such an assumption seems to be close to Chomsky's view of the performance being a reflection of competence as he considers "competence" to be "the speaker-hearer's knowledge of his language" and "performance" to be "the actual sue of language in a concrete situation" (Chomsky, 1965).

Scholars of this approach are keen on differentiating between errors and mistakes. Ellis (1997) distinguishes between the two saying, "[errors] reflect gaps in a learner's knowledge; they occur because the learner does not know what is correct. [Mistakes] reflect occasional lapses in performance; they occur because, in a particular instance, the learner is unable to perform what he or she knows". Corder (1981) uses two different terms: "errors of competence" for "systematic error" and "error of performance" for "unsystematic error". Ellis's terms sound swift whereas Corder's are explanatory as "error" is attributed to its sources: competence and performance. James (1998) goes further in classifying deviations of performance errors into 'slips/lapses', 'mistakes', 'errors' and 'solecisms' - deviation in norms and syntax. Errors, in their turn, are also categorized by their nature or cause into different types like "developmental", "interalingual", "interference", and "unique" (Richards, 1971; Duly \& Burt, 1974). Details about such classifications and the scholars" views of them are not found necessary to be presented in this study due to its scope.

Moreover, Ellis (1997) suggests two ways to identify errors from mistakes: one by checking the consistency of the learner's deviations and another by checking the learner's ability in correcting their deviations; the consistent and uncorrected ones are errors.

EA is found beneficial for feedbacking both teachers in terms of their teaching materials, methods, and techniques. In addition, EA enables teachers to reconsider the effectiveness of syllabuses' designs and the time needed for teaching their sections. In Richards' (1984) preface, Candlin recaps the merits of EA stating:

From the standpoint of practical teaching we have become more aware of the long-term value of Error Analysis as a chief means of both assessing the pupil's learning in general and the degree of match between his learning 'syllabus' and the teacher's teaching one.

Despite the advantages provided by the approach of EA especially to language teachers, it lost its popularity to some extent due to a number of drawbacks, like its inconsistent terminology to account for errors, its restrict focus on learners' errors ignoring their correct uses and on their accuracy ignoring their fluency (see Alkhresha, 2016). Additionally, EA is accused of not being able to detect the learners' strategy avoidance which they often follow whenever encountering a L2 feature that they find challenging or difficult (James, 1998). Thus, an analysis has been felt to be requisite to account for the learner language whose system includes features which 
are neither of L1 nor L2. In short, EA could not provide a comprehensive account to the achievement of L2 learners.

\subsection{Interlanguage Development}

The birth of Interlanguage as a theory formally dates back to 1972 when Larry Selinker issued his article, Interlanguage. Selinker is thought to be inspired by Uriel Weinreich, who had touched upon this topic but uncompleted it due to his premature death and this point was alluded by Selinker (1972) himself in the above mentioned article. He criticizes Weirneich saying "although Weirneich takes up many linguistic and some psychological questions, he leaves completely open questions regarding the psychological structures within which he assumes 'interlingual identifications exist".

Selinker (ibid) coined his term latent psychological structure after Lenneberg's latent language structure which he thought to have secondary role in SLA. To Lenneberg (1967), a child's brain has a natural inclination to acquire a language. According to Elena (1990), Lenneberg assumes the existence of latent language structure which is an already formulated arrangement in the brain and then throughout maturational stages, infant transform it into the realized structure of a particular grammar. Importantly, the psychological latent structure of Selinker does not touch upon critical period, nor any grammatical concept, nor the realization of a particular grammar structures of the L2.

Apparently, IL as a theory dealing with SLA has benefited from both of the approaches of CA and EA albeit it researches in a different area. Firstly, CA compares the norms of two languages to predict the difficulties which may face the learner of either language as an L2 and EA investigates the errors of L2 learners to find out the problematic norms for L2 learners whereas IL attempts, via their errors, to account for the mental process responsible for the specific features of the language of L2 learner. Secondly, both CA and EA are interested in what Chomsky identifies as performance - the learner's product, spoken or written-but IL's focus is competence, i.e. the learner's knowledge, specifically the psychological competence. Thirdly, Corder (1967) believes that learning an L2 process makes use of the hypotheses the learner has on their mother language and thus, the more similarities between the two systems of languages, the easier the process will be. But, Selinker (1972) hypothesizes that an L2 learner attempts to build their own assumptions about the L2 they learn and the majority of L2 learners develop a separate linguistic system, which he calls interlanguage, without denying the possibility of utilizing the same mechanism of L1 acquisition. He suggested that those adults who successfully achieve native speaker proficiency in an L2 do so because they "have reactivated the latent language structure".

What identifies interlanguage in its view of L2 learners' errors, is that it perceives the L2 which the learner speaks to be an independent a language system which is neither similar to L1 nor L2, without denying their interference in its development (Lennon, 2008). The oppositeness in the directions of approaching L2 problems between EA led by Corder and Slelinker's IL is probably attributed to the difference in researching between the British and the American schools. Davis (1991) postulates:

The American Linguistics-Applied tradition starts with linguistic theory and looks for ways to apply it most usefully on practical problems such as language teaching; the British Applied-Linguistics tradition starts with the practical problems and then seeks theoretical (and/or practical) ways to understand and resolve those problems.

Selinker follows the American model, which involves building a theory and then applying it, but Corder follows the British model, which attempts from practice to arrive at a theory, i.e. the American model of research is deductive whereas the British is inductive. Actually, the skeleton of IL theory can be represented in Selinker's endeavor to find out if there was a linguistic system behind the performance of an L2 learners and this led to other important related questions to follow (Tarone, 2014).

Throughout the recent years of research, the theory of IL has seen a number of changes compared to its 1972 version. In her article, Interlanguage, Tarone (1994) accounts in detail for these newly revised principles which can be summarized in the following list:

1). IL hypothesis should not only be restricted to apply to adults, but children as well.

2). Selinker viewed IL as unnatural language for it does not have to obey language universals whereas Adjěmian (1976), followed by others, perceive ILs to be natural languages (like any other human ordinary languages).

3). Recent researchers have noticed that learners could produce more fluent and transfer-free IL in some social contexts than in others; something which was not accounted for in the past.

4). Selinker's view of fossilization was that it was an inevitable phenomenon of neurolinguistic feature. New IL researchers argue that the reason is not solely neurolinguistic; it can be sociolinguistic as some like to identify 
themselves with the native language, and this implies that fossilization may not necessarily be inevitable.

\subsection{Basic Processes of IL}

Adopting a latent psychological structure as framework for his theory, Selinker (1972), suggests five main processes according to which SLA occurs. They are briefly:

1). Language transfer

2). Overgeneralization of target language rules

3). Transfer of training

4). Strategies of L2 learning

5). Strategies of $\mathrm{L} 2$ communication

In the following sections, according to their importance, light is to be shed on each of these processes.

\subsubsection{Language Transfer (LT)}

Technically, Arabski (2006) presents two definitions of transfer: one behaviorist and another applied linguistic. "Behaviorist psychologists, who first defined 'transfer' technically, used it to refer to a process described as the automatic, uncontrolled, and subconscious use of past learner behaviors in the attempt to produce new responses". On the other hand, the applied linguists define it as "a process in foreign language learning whereby learners carry over what they already know about their first language to their performance in their new language" (see, e.g. Lado, 1957; Corder, 1971; Crystal's Dictionary of Linguistics and Phonetics, 1980).

It may be worth mentioning that language transfer (LT) is also referred to as L1 interference and as crosslinguistic influence accounting for communicators accessing L1 system while using L2, i.e. applying linguistic knowledge from L1 to L2.

When accounting for language transfer (LT) in the theory of IL, it is quite common to find the light being shed on the role of the learner's mother tongue in SLA and the consequences resulted from such involvement.

To Selinker (1972), language transfer (LT) is a process that indicates the demonstration of the rules and subsystems of L1 in the performance of L2 learners - their IL.

Almost similarly, yet briefly, Ellis (1997) defines LT as “the process by which the learner's L1 influences the acquisition and use of an L2".

In his distinctive attempt to accentuate the role of mother tongue in SLA, Coder (1993) appears unhappy about using the terms transfer or interference and calls for coining alternative terms arguing that the influence of L1 is richer and more complex than what the theory of transfer has assigned for. However, he affirms LT postulating the occurrence of "more incorrect mother-tongue-like features in the learner's performance in the earlier stages than in the later stages" (p. 23).

Positively viewing the developmental process of learners SLA, Montrul (2014) considers transfer as "a defining feature of the cognitive process of SLA".

In all the definitions above, apparently, LT is conceptualized as a mother-tongue-based-process which is responsible for unnatural production of L2. Montrul's view of LT, which stresses the cognition aspect, sounds positive as it implies that such a feature is an indication of the existence or development of the process of learning a second language.

Unlike CA hypothesis which perceives L1 to be the only developer of the language learner, IL theory suggests other processes to shape the L2 besides the process of native LT. As for the amount of the occurrence of LT in L2, the prediction, to a great extent, is based on the distance between L1 and L2. The more the two languages have features in correspondence, the more chances for L1 there will be to conduct positive influence on learning L2 and vice versa.

\subsubsection{Positive LT vs. Negative LT}

Scholars, starting from the behaviorists, classify language transfer into two types according to the facilitating role of L1 in providing corresponding features for the learner to match the ones in L2. Thus, whenever the learner finds $\mathrm{L} 1$ features have equivalent in $\mathrm{L} 2$, the transfer is known as positive transfer.

On the contrary, the lack of such equivalence of correspondence will lead to what is labeled as negative transfer also called L1 interference. And due to the state that positive transfer results in correct language production and negative transfer leads to errors, it is noticed that the latter type is researched and highlighted more than the first 
type.

Nemser (1971) puts these types swiftly when referring to the suppositions of CA approach. He states that "the approach is based on the a general view of learning according to which prior learning affects subsequent learning, positively where the new skill coincides with one already mastered, negatively where they are opposed". What is to be borne in mind of Nemser's prior learning is that it covers both knowledge of L1 and the learner's recent experience of $\mathrm{L} 2$-the IL.

An example that may clarify both of the types is that Kurdish EFL learners find no problem in pronouncing words with the phonemes "p" or "v" because of the existence of the sounds $/ \mathrm{p} /$ and $/ \mathrm{v} /$ in Kurdish language and realized by the Kurdish letters " " and " "ڤ" respectively, which makes a positive transfer. In contrast, the lack of the $/ \theta /$ and $/ \delta /$ makes the Kurdish EFL learners pronounce words with such phonemes imperfectly and turn them into $/ \mathrm{s} /$ and $/ \mathrm{z} /$ respectively making negative transfer. It can be noticed that within the frame of contrastive analysis theory, the similarities between two languages are chances for positive transfer whereas the dissimilarities are opportunities for negative transfer. An example of IL sociopragmatics could be when students vocatively use the word teacher. In English, the students do not draw the teacher's attention by saying teacher as Kurdish students do in different stages of their language learning.

\subsubsection{Near LT vs. Far LT}

Another distinction is suggested between near transfer and far transfer by (Kirwan, 2009) and (Perkins \& Salmon, 1992). The nearness of transfer is determined by the similarity between of the context of learning and the background knowledge the learners already have. Near transfer can be illustrated by a case of Kurdish student learning Persian language, which are both members of the same language family-Endo-Iranian. And an example of far transfer can be a case of Kurdish students learning Japanese, for instance, which belongs to Japonic language family. Comparing the two cases, the near is more likely to be positive than the far.

\subsubsection{Overgeneralization of TL Rules}

L2 learners may tend to overgeneralize some of the grammatical rules of the L2 or some of its semantic features (Selinker 1972). The overgeneralization involves the application of grammatical or morphological rules in contexts or cases where such rules do not apply, like adding past tense marker -ed to irregular verbs such as teach forming *teached. Or using the verb ride, which is acceptable with bicycle and horse, with car and saying something like *He is riding a car. Overgeneralization-based errors committed by L2 learners are almost similar to the ones children make in their mother tongue.

\subsubsection{Transfer of Training}

A second central process of IL performance is referred to by Selinker (1972) as transfer of training. It occurs when the items, rules, and subsystems, which are fossilizable, are resulted from identifiable items in training procedures. What teachers aim at in their training courses is to enable the learners transfer the knowledge gained in the class to real life situations outside the class environment properly. Thus, the training will be considered successful if it makes the learners successful in applying it when needed, for instance, making requests outside the instruction environment after having covered related conversational extracts in the class.

It goes without saying that training transfer can be positive if the training course facilitates the mission for the trainees to convey their communicative messages in similar situations in their everyday life. On the other hand, if such facilitation did not occur, then the training transfer is negative. The criterion of positivity and negativity of such transfer, then, is the success of the learners in adapting their class acquired knowledge to real world situations.

\subsubsection{Strategies of L2 learning}

Many scholars discarded behaviorism and embraced cognitive approaches. Such disposition was basically inspired by Chomsky's theory of transformational-generative grammar which argues that many original utterances are generated by the language learner depending on their own underlying competence, which implied that a key role for the learner in building their competence. Accordingly, they started researching the learners' techniques and strategies to develop their L1 or L2.

The valuable role of strategies in language learning is unquestionable among strategy specialists who believe that "learners with strategic knowledge of language learning, compared with those without, become more efficient, resourceful, and flexible, thus acquiring a language more easily" (Tseng, Dörnyei, \& Schmitt, 2006). In the same vein, Fedderholdt (1998) stresses the idea of cultivating language learners' skills by providing them with appropriate language learning strategies. 
The term strategies is seen by Weinstein et al. (2000) as "any thoughts, behavioures, beliefs, or emotions that facilitate the acquisition, or later transfer of new knowledge and skills". And, of course, in the field of language learning, the new knowledge and skills are represented by the linguistic system (competence) and behavioure (performance).

Learning strategies may simply cover all the mental processes that are activated when a linguistic task is performed. And in the context of an L2 class, the strategies involve the learner's behaviors in response to acquiring an L2. To McDonough (1995), L2 strategies encompass language skills, language processes, mechanisms to compensate for lack of language, and action plans.

In her famous article, What the "Good Language Learner" can Teach Us?, Rubin (1975) states her concept of learning strategies as "the techniques or devices which a learner may use to acquire knowledge".

Tarone (1981) views language learning strategy in a broader frame covering the linguistic and the metalinguistic skills in the L2 which are followed in developing the interlanguage competence of the learner. She perceives language learning strategies as "an attempt to develop linguistic and sociolinguistic competence in the target language to incorporate these into one's interlanguage competence" (p. 290).

O'Malley et al. (1985) has adopted the definition of learning strategies as being "operations or steps used by a learner that will facilitate the acquisition, storage, retrieval or use of information". This definition, apparently, underlines the learner's competence development and performance.

Wenden (1987) defines language learning strategies as "language learning behaviors learners actually engage in to learn and regulate the learning of a second language".

To put it briefly, it can be concluded from the definitions mentioned above that strategies of L2 learning underlie all what a learner does in their attempt to acquire the language in terms of both its system and behavior.

Researchers of learning strategies have different taxonomies for the strategies with different main and subcomponents. The prominent and best known classifications are those of Rubin (1987), O'Malley and Chamot (1990), and Oxford (1990).

Rubin's categorization, which is pioneering, is more abstract than the others. She highlights two major strategies of learning:

1). Cognitive strategies, which are related to the learner's intrapersonal approach to language learning in terms of problem-solving. They involve a list of sub-strategies: clarification, inductive inference, deductive reasoning, practice, memorization, and monitoring.

2). Metacognitive strategies, which are related to the learner's intrapersonal approach to language learning in terms of self-regulating and self-directing. They involve planning, prioritizing, setting goals, and self-management.

As for O'Malley and Chamot (1990), they classify the strategies into three categories (cited in Gao, 2010):

1). Metacognitive strategies, which include managing or regulating one's own efforts in the learning process.

2). Cognitive strategies, which represent related cognitive processing, such as inferencing, guessing and relating new information to old, etc.

3). Socioaffective strategies, which show how to interact with other learners and manage one's feelings in the learning process.

Oxford (1990) presents a more detailed categorization of language learning strategies. She lists six of them:

1). Cognitive strategies, which are related to how learners think of their learning.

2). Metacognitive strategies, which tell about how they manage their own learning.

3). Memory strategies, which encompass how learners remember and retain language.

4). Compensation strategies, which sketch out how learners make up the limited language to achieve successful language use.

5). Social strategies, which account for how learners learn language through social interaction.

6). Affective strategies, which show how learners adjust their affective status in the learning process.

Apparently, compared to O'Malley, Oxford in this form of taxonomy is more precise and informative as she splits the socio-affective into two seperate strategies and adds the memory strategy to the list. The distinction of Oxford's taxonomy, compared to other categorizations, is approved by Ellis (1994) stating that it is "perhaps the 
most comprehensive classification of learning strategies to date".

It is worthy to mention that researching in second language learning strategies started to fade out in the beginning of the new millennium. Language learning strategies research came under the hummer of severe criticism in terms of definition, categorization, and research methodologies. Psycholinguists, Dörnyei and Skehan (2003), Dörnyei (2005), Woodrow (2005), Tseng et al. (2006), and Grenfell and Macaro (2007) are best examples of critiques of language learning strategies. Covering the details of the drawbacks of language learning strategies falls out of the scope of this study (for a review of the major critiques, see Rose 2012).

In a reaction to the barrage of criticism learning strategies received, present researches prefer using strategic learning instead, "based on the notion of self-regulation drawn from the field of educational psychology" (Tseng, Dörnyei, \& Schmitt, 2006).

\subsubsection{Strategies of L2 communication}

Communication strategies (CS) as a term is technically used to cover all the ways an L2 learner uses to communicate their ideas and intentions relying on the limited linguistic knowledge of the L2. This concept is clearly detected in Bialystok's (1983) definition of CS "all attempts to manipulate a limited linguistic system in order to promote communication". Thus, such strategies, to certain extent, can be understood as problem-solving ways to facilitate communication in $\mathrm{L} 2$.

The strategies which L2 learners resort to communicate meanings vary according to the complexity of the intended meaning. They range from using synonyms, paraphrasing, literal translating, generalizing, approximating, roundabout speaking (circumlocution), to pointing, and miming. To clarify these strategies, the examples below will quite be helpful. To refer to a magic marker, an L2 learner who does not know the name can be expected to use one of these strategies:

a). Pen (generalization)

b). Whiteboard magic (approximation)

c). Special pen used for writing on whiteboards (circumlocution)

d). Erasable whiteboard pen (paraphrase)

Various taxonomies have been set for CS by scholars working in the field of IL like Tarone (1977 \& 1980) who has amply approached the classification of CS with rich details and examples, which need much space that this study cannot afford.

\subsection{On the Psychology of IL}

Before the IL research boom in 1970s, the behaviorist approach of CA hypothesis predicted the errors of L2 learners to be caused by their L1 transfer and that was because of its view that L1 was the sole source to shape L2. Then thanks to Chomsky's Universal Grammar, which originally approached L1, researchers started investigating if learners of L2 could access the built-in linguistic system that Chomsky claimed.

According to Tarone (1994), Corder $(1967,1981)$ was the first and most persuasive scholar to develop an alternative framework: the idea that L2 learners do not begin with their native language, but rather with a universal 'built-in syllabus' that guides them in the systematic development of their own linguistic system, or 'transitional competence'. This entails that no total or heavy reliance on L1 is conducted by L2 learners while developing their L2 knowledge - yet, L1 interference is not denied in the theory.

Explaining the aspects of the psychology of L2 learning is announced to be the goal of Selinker (1972) as he proposed in his seminal article, Interlanguage. He built on what Weinreich (1953, as cited in Selinker, 1972) had left undetermined relating to psychological structures in what the latter termed interlingual identifications. Selinker's contribution was identifying a psychological structure and postulating that it was latent in the brain.

It can be noticed that Selinker's latent psychological structure is coined after the latent language structure of Lennberg (1967, as cited in Selinker, 1972) who finds it as a biological counterpart to universal grammar. Selinker (1972) conceptualizes SLA to happen via accessing the L1 latent language structure and reactivating it to a certain extent. Taking this literally, one could assume that no role is found for the process of cognition which involves having some implicit knowledge depending on which one produces their communicative messages. Actually, Selinker does not deny the psychological role of cognition in acquiring L2 though he believes in the Weinreich's latency of language structure. IL theory identifies the role of L2 learners for being present actively in developing their own rules out their experience in the L2 by accessing that latent system.

Apparently, considering the central processes of interlanguage that Selinker (1972) sets reveals the cognitive 
approach of SLA within the theory of interlanguage. The processes of transfer in terms of learning, training and overgeneralizing are all indicators of cognition. This notion is alluded in Tarone's (1994):

The interlanguage is viewed as a separate linguistic system, different from both the learner's 'native language' (NL) and the 'target language' (TL) being learned, but linked to both NL and TL by interlingual identifications in the perception of the learner.

Accounting for the cognitive dimension in the process of SLA is a merit of IL theory and enhances its practicality in the domain.

\section{Conclusion}

What one may arrive at about the three models covered in the previous sections is that all of them have had a considerable contribution in applied linguistics especially in the domain of SLA. Each has helped in cultivating L2 teaching methods and materials besides enhancing the efficiency of L2 learners in their journey of acquiring an L2.

Thanks to its focus on contrasting structures of different languages, CA provides the requisite row material for teachers of translation in the class. It can help learners explicitly learn about the grammatical difference between their native language and the L2, which may reduce their errors at this level of language. Similarly, CA may enable teachers to learn about the type of the grammatical errors of their students. Nonetheless, CA is not quite reliable in predicting L2 learners' errors and fails to account for the role of L2 itself in terms of the development the learners achieve or the L2-based errors they make.

On the other hand, EA despite its benefits for researchers, educators and L2 learners, it is not a balanced comprehensive theory as it confines measuring L2 learners' knowledge of using the L2 to their errors only - no feedback is carried out to their proper performance. Educationally, learners like their positive performance to be approved and acknowledged, an act which certainly encourages them to work harder.

To the theory of IL, errors are found to be signs of development of the linguistic knowledge of the L2 learner, and indicators of the strategies adopted by the L2 learners. Unlike CA and EA, IL considers the cognitive part in L2 learning via investigating the strategies employed by the learners in learning and in communication. Yet, IL fails to clearly identify which of its five SLA basic processes is the source of a given error; moreover, it finds difficulty in ascertaining the level an L2 learner reaches in his/her journey of SLA.

\section{References}

Al-Khresheh, M. (2016). A review study of error analysis theory. Internation Journal of Humanities and Social Research, 2, 49-59.

Arabski, J. (2006). Language transfer in language learning and language contact. In J. Arabski (Ed.), Cross-linguistic influences in the second language lexicon (pp. 13-21). Totonto: Multilingual Matters.

Archer, D., \& Grundy, P. (2011). Introduction. In D. Archer (Ed.), The pragmatics reader (pp. 1-10). New York: Routledge.

Bach, K. (2004). Pragmatics and the philosophy of language. In L. R. Horn, \& G. Ward (Eds.), Handbook of pragmatics (pp. 463-487). Oxford: Blackwell Publishing Ltd.

Bardovi-Harlig, K. (2001). Bardovi-Harlig, K. (2001). Evaluating the empirical evidence: Grounds for instruction in pragmatics. In G. Kasper, \& K. Rose (Eds.), Pragmatics and language teaching (pp. 11-32). Cambridge: Cambridge University Press. https://doi.org/10.1017/CBO9781139524797.005

Bialystok, E. (1983). Some factors in the selection and implementation of communication strategies. In C. Farch, \& G. Kasper (Eds.), Strategies in interlanguage communication (pp. 100-119). London: Longman.

Broslelow, E. (1992). Transfer and universals in second language ephenthesis. In S. M. Gass, \& L. Selinker (Eds.), Language transfer in language learning (pp. 71-86). Amsterdam: John Bejamins Publishing Company.

Brown, H. D. (1987). Principles of language learning and teaching. New Jersy: Prentics Hall.

Cai, L., \& Wangi, Y. (2013). Interlanguage pragmatics in SLA. Theory and Prcticein Language Studies, 3(1), 142-147. https://doi.org/10.4304/tpls.3.1.142-147

Canale, M., \& Swain, M. (1980). Theoretical bases of communicative approach to second language teaching and testing. Applied Linguistics, 1, 1-47. https://doi.org/10.1093/applin/I.1.1

Canale, M. (1983). From communicative competence to communicative language pedagogy. In J. Richards, \& R. 
W. Schmidt (Eds.), Language and communication (pp. 2-14). London: Longman.

Chomsky, N. (1965). Aspects of The Theory of Syntax. Cambridge: M.I.T Press.

Chomsky, N. (1978). Language and unconscious knowledge. In J. H. Smith (Ed.), Psychoanalysis and language (pp. 3-44). New Haven, Conn: Yale University Press.

Corder, S. (1967). The significance of learners' errors. In J. C. Richards (Ed.), Error analysis:perspectives on second language analysis (pp. 19-27). London: Longman.

Corder, S. (1993). A role of the mother tongue. In S. Gass, \& L. Selinker (Eds.), Language transfer in language learning (pp. 18-31). Amsterdam: John Benjamins.

Corder, S. P. (1971). Idiosyncratic dialects and error analysis. International Review of Applied Linguistics (IRAL), 9(2), 147-160. https://doi.org/10.1515/iral.1971.9.2.147

Corder, S. P. (1981). Error analysis and interlanguage. Oxford: Oxford University Press.

Crystal, D. (1980). A dictionary of linguistics and phonetics (6th ed.). Malden, USA: Blackwell Publishing House.

Davis, A. (1991). British applied linguistics: the contribution of S. Pit Corder. In R. Philipson, K. Eric, L. Selinker, S. M. Sharwood, \& M. Swain (Eds.), Foreign/second language research: A commemorative volume for Clause Farch (pp. 52-60). Clevendon: Multilingual Matters.

De Prada Creo, E. (1990). The Process of Fossilaztion in Interlanguage. The 9th Annual Meeting of the World Congress of Applied Linguistics (pp. 1-19). Thessaloniki, Greece: ERIC Document Reproduction Service.

Dörnyei, Z. (2003). Individual differences in second language learning. In C. J. Doughty, \& M. H. Long (Eds.), The handbook of second language acquisition (pp. 589-630). Oxford: Blackwell. https://doi.org/10.1002/ 9780470756492.ch18

Dualy, H., \& Burt, K. (1974). Error and strategies in child language acquistion. TESOL Quarterly, 8(2), 129-136. https://doi.org/10.2307/3585536

Ellis, R., \& Barkhuizen, G. (2005). Analyzing learner language. Oxford: Oxford University Press.

Ellis, R. (1994). The study of second language acquisition. Oxford: Oxford University Press.

Ellis, R. (1997). Second language acquisition. Oxford: Oxford University Press. https://doi.org/10.1017/S02722 63197002027

Fedderholdt, К. (1998 йил 20-April). The language teacher. Retrieved 2017 йил 20-March from http://www.jalt-publications.org/old_tlt/files/98/apr/fedderholdt.html

Fetzer, A. (2011). Pragmatics as linguistic concept. In W. Bublitz, \& N. R. Norrick (Eds.), Foundations of pragmatics (pp. 23-50). Berlin: De Gruyter Mouton. https://doi.org/10.1515/9783110214260.23

Fries, C. (1945). Teaching and learning English as a foreign language. Ann Arbor, Michigan: University of Michigan Press.

Gao, X. (2010). Strategic language learning: the role agency and context. Clevedon, UK: Multilingual Matters. https://doi.org/10.1111/j.1467-9922.2010.00573.x

Gass, S. (2001). Second Language Acquisition: an introductory course (2nd ed.). Mahawa, New Jersy: Lawrence Erlbum Associates.

Hill, T. (1997). The development of pragmatic competence in an EFL context. Philadephia: Temple University.

Hymes, D. (1972). On communicative competence. In J. B. Pride, \& J. Holmes (Eds.), Sociolinguistics: selected readings (pp. 269-293). Harmondsworth: Penguin.

Hymes, D. (1974). Foundations in sociolinguistics: an ethnographic approach. Philadlephia: University of Pennsylvania Press.

Iftantidou, E. (2014). Pragmatic competence and relevance. Amsterdam: John Benjamins Publishing Company. https://doi.org/10.1075/pbns.245

James, C. (1980). Contrastive analysis. London: Longman.

James, C. (1998). Errors in language learning and use. London: Longman.

Kasper, G. (1996). Development issues in interlanguage pragmatics. Studies in Second Language Acquistion, 18(2), 149-169. https://doi.org/10.1017/S0272263100014868 
Kasper, G. K. (1993). Interlanguage pragmatics. Oxford: Oxford University Press.

Kasper, G. (1979). Errors in speech act realization and use of gambits. The Candian Modern Language Review, 35(3), 395-406. https://doi.org/10.3138/cmlr.35.3.395

Kasper, G. (1992). Pragmatic Transfer. Second Language Research, 8(3), 203-231. https://doi.org/10.1177/026 765839200800303

Kasper, G. (1998). Interlanguage pragmatics. In B. H. (Ed.), Learning foreign and second languahes (pp. 183-208). New York: The Modern Language Association of America.

Kecskes, I. (2015). How does pragmatic competence develop in bilinguals. Internation Journal of Multilingualism, 12(4), 419-434. https://doi.org/10.1080/14790718.2015.1071018

Kirwan, C. (2009). Improving learning transfer: a guide to get more out of what you put in your training. Burlington, VT.: Gower Publishing Company.

Kissine, M. (2012). Sentences, utterances, and speech acts. In A. Keith, \& K. Jaszczolt (Eds.), The Cambridge handbook of pragamtics (pp. 169-190). Cambridge: Cambridge University Press. https://doi.org/10.1017/ CBO97 81139022453.010

Kompa, N., \& Meggle, G. (2011). Pragmatics in modern philosophy of language. In B. Wolform, H. Juker, \& K. P. Schneider (Eds.), Foundations of Pragmatics (pp. 203-228). Berlin/Boston: Walter de Gruyter Mouton. https://doi.org/10.1515/9783110214260.203

Lado, R. (1957). Linguistics across cultures. Ann Rbor, Michigan: Michigan University Press.

Leech, G. (1983). Principles of pragmatics. London: Longman.

Lenneberg, E. (1967). Biological foundations of language. New York: Wiley.

Lennon, P. (2008). Contrastive Analysis, Error Analysis, Interlanguage. In S. Gramley, \& V. Gramley (Eds.), Bielefeld Introduction to Applied Linguistics (pp. 51-60). Bielefeld: Aisthesis.

Marmaridou, S. (2000). Pragmatic meaning and cognition. Amsterdam: John Benjamins. https://doi.org/10.1075 /pbns. 72

McDonough, S. H. (1995). Strategy and skill in learning a foreign language. London: Edward Arnold.

Mey, J. L. (1993). Pragmatics: an introduction. Massachussetts: Blachwell. https://doi.org/10.1016/0378-2166 (93)90013-F

Montrul, S. (2014). Interlanguage, transfer, and fossilzation: beyond second language acquisition. In Z. Han, \& E. Tarone (Eds.), Interlanguage: forty years later (pp. 75-105). Amsterdam: John Benjamins.

Nemser, W. (1971). Approximative system of foreign language. International Review of Applied Linguistics (IRAL), 9(2), 115-123.

Nunan, D. (1988). Learner-centered curriculum. Cambridge: Cambridge University Press. https://doi.org/ 10.1017/ CBO9781139524506

O'malley, J. M., \& Chmot, A. U. (1990). Learning strategies in second language acquisition. Cambridge: Cambridge University Press. https://doi.org/10.1017/CBO9781139524490

Oxford, R. L. (1990). Language learning strategies: what every teacher should know. New York: Harper \& Row.

Richards, J. (1971). A Non- Contrastive Approach to Error Analysis. Journal of ELT, 25, 204-219. https://doi.org/10.1093/elt/XXV.3.204

Richards, J. C., \& Schmidt, R. (2002). Longman dictionary of teaching and applied linguistics. London: Pearson Education Ltd.

Rintell, E. (1979). Getting your speech act together: the pragmatic ability of second learners. Working Papers on Bilingualism, 17, 97-106.

Rose, H. (2012). Language learning strategy research: Where do we from here? Studies in Self-Access Learning, $3(2), 137-148$.

Rubin, J. (1975). What the 'good language learner' can teach us. TESOL Quarterly, 9, 41-51. https://doi.org/ $10.2307 / 3586011$

Sadock, J. (2004). Speech acts. In L. R. Horn, \& G. Ward (Eds.), The handbook of pragmatics (pp. 53-73). Malden: Blackwell Publishing. 
Saville, M. (2006). Introducing second language acquisition. Cambridge: Cambridge University Press.

Scarcella, R. (1979). On speaking politely in a second language. In On TESOL (pp. 275-287). Washington, DC: TESOL.

Searle, J. (1979). Expression and meaning. Cambridge: Cambridge University Press. https://doi.org/10.1017/ CBO9780511609213

Selinker, L. (1972). Interlanguage. International Review of Applied Linguistics in Language Teaching, 10, 209-231. https://doi.org/10.1515/iral.1972.10.1-4.209

Sridhar, S. N. (1976). Contrastive analysis, error analysis and interlanguage: Three phases of one goal. Indian Linguistics, 37(3-4), 259-281.

Takač, V. P. (2008). Vocabular Learning Strategies and Foreign Language Acquisition. Toronto: Mutilingual Matters Ltd. https://doi.org/10.21832/9781847690401

Tarone, E. (1977). Conscious communication strategies in interlanugae: A progress report. In H. Brown, C. A. Yorio, \& R. C. Crymes (Eds.), On TESOL Quartely 77 (pp. 194-203). Washington: TESOL.

Tarone, E. (1980). Communication strategies: foreigner talk and repair in intelanguage. Language learning, 30(2), 417-431. https://doi.org/10.1111/j.1467-1770.1980.tb00326.x

Tarone, E. (1981). Some thoughts on the notion of "communication strategy." TESOL Quarterly, 15, 285-295. https://doi.org/10.2307/3586754

Tarone, E. (1994). Interlanguage. Elsiver Ltd, 4, 1715-1719.

Tarone, E. (2014). Enduring questions from the intelanguage hypothesis. In Z. Han, \& E. Tarone (Eds.), Interlanguage 40 years later (pp. 7-26). Amsterdam: John Benjamins Publishing Company. https://doi.org/10.1075/11lt.39.03ch1

Thomas, J. (1983). Cross-cultural pragmatic failure. Applied Linguistics, 4(2), 92-112. https://doi.org/10.1093 /applin/4.2.91

Trosborg, A. (1995). Interlanguage pragmatics: Requests, complaints, and apologies. New York: Mouton de Gruyter. https://doi.org/10.1515/9783110885286

Tseng, W., Dornyei, Z., \& Schmidt, N. (2006). A new approach to assessing strategic learning: the case of self-regulation in vocabulary acquisition. Applied Linguistics, 27(1), 78-102. https://doi.org/10.1093/app lin/ami046

VanPatten, B., \& Benati, A. G. (2010). Key terms in second language acquisition (p. 100). London: Continuum.

Wardhaugh, R. (1970). The contrastive analysis hypothesis. TESOL Quarterly, 4, 123-130. https://doi.org/10.23 $07 / 3586182$

Weinstein, C. E., Husman, J., \& Dierking, D. R. (2000). Self-regulation inventions with a focus on learning strategies. In P. Bockaerts, P. R. Pintrich, \& M. Zeinder (Eds.), Handbook of self-regulation (pp. 727-747). San Diego, CA: Academic Press.

Wenden, A. (1987). How to be a successful learner: Insights and perspectives from L2 learners. In A. Wenden, \& J. Rubin (Eds.), Learner strategies in language learning. New Jersey: Prentice Hall.

White, L. (2003). On the nature of interlanguage representation. In C. J. Doughty, \& M. H. Long (Eds.), Handbook of second language acquisition (pp. 18-42). Malden, MA: Blackwell Publishing Ltd. https://doi.org/10.1002/9780470756492.ch2

Whitman, L. (1970). Contrastive analysis. Language Leearning, 20, 191-197. https://doi.org/10.1111/j.146 7-1770.1970.tb00476.x

Woodrow, L. (2005). The challange of measuring language learning strategies. Foreign Language Annals, 38(1), 90-98. https://doi.org/10.1111/j.1944-9720.2005.tb02456.x

Xia, Y. (2014). Language Theories and Language-from Traditional Grammar to Functionalism. Journal of Language Teaching and Research, 5(3), 559-565. https://doi.org/10.4304/jltr.5.3.559-565

Yule, G. (1985). The study of language (6th ed.). Cambridge: Cambridge University Press.

Yule, G. (1996). Pragmatics. Oxford: Oxford University Press.

Zeng, X. M. (2006). A study on Chinese EFL learners' interlanguage pragmatic competence in the speech act of 
apology (MA thesis). South-west Jiaotong University.

\section{Copyrights}

Copyright for this article is retained by the author(s), with first publication rights granted to the journal.

This is an open-access article distributed under the terms and conditions of the Creative Commons Attribution license (http://creativecommons.org/licenses/by/4.0/). 